\title{
The antioxidant activity and stability of yogurt fortified with rosella (Hibiscus sabdariffa Linn) calyx extract
}

\author{
Nurkhasanah Mahfudh*, Amraini Amelia \\ Department of Pharmaceutical Analysis and Medical Chemistry \\ Faculty of Pharmacy, Universitas Ahmad Dahlan Yogyakarta \\ Jl. Prof. Dr. Soepomo, Janturan, Yogyakarta, Indonesia
}

Submitted: 13-05-2020

Reviewed: 13-06-2020

Accepted: 12-10-2020

\begin{abstract}
Roselle calyx (Hibiscus sabdariffa Linn) contains many anthocyanins. The purpose of this study was to determine the anthocyanin stability and antioxidant activity of rosella calyx extract and rosella calyx fortified in yogurt. Roselle calyx extract (Hibiscus sabdariffa Linn) was obtained by the infundation method using water at $90{ }^{\circ} \mathrm{C}$ for 15 minutes. Rosella calyx extract was made into yogurt with a concentration of $0 \%, 2 \%, 4 \%$ and $8 \%$, full cream liquid milk $13 \%(100 \mathrm{ml})$, and a $5 \%$ bacterial starter combination concentration $(1: 1 \mathrm{~b} / \mathrm{v})$. The yogurt evaluation included a stability test with storage at $4^{\circ} \mathrm{C}$ and antioxidant activity using the DPPH method on $0,7,14,21$, and 28 days. The data was statistically analyzed using Multivariate Analysis of Variance (MANOVA). The anthocyanin stability of the three samples, namely roselle extracts of $2 \%, 4 \%$, and $8 \%$, significantly different (p $<0.05$ ) for each concentration of roselle calyx extract and the antioxidant activity of roselle calyx yogurt in the three samples $2 \%, 4 \%$ and $8 \%$ were significantly different for each concentration of rosella calyx extract added to yogurt. During storage, anthocyanin stability and antioxidant activity of rosella calyx yogurt extract on day 0 to 7 did not differ significantly, while 14 to 28 were significantly different. The $4 \%$ and $8 \%$ concentrations of rosella calyx yogurt produce optimal yogurt formula.
\end{abstract}

Keyword: yogurt, anthocyanins, Hibiscus sabdariffa Linn, DPPH

\footnotetext{
*Corresponding author:

Nurkhasanah Mahfudh

Department of Pharmaceutical Analysis and Medical Chemistry

Faculty of Pharmacy, Universitas Ahmad Dahlan

J1 Prof.Dr. Soepomo, Janturan, Yogyakarta, Indonesia

Email: nurkhas@gmail.com
} 


\section{INTRODUCTION}

Yogurt is a fermented milk product with a higher nutritional value than milk, a primary ingredient in making yogurt. Yogurt contains probiotic bacteria that provide health effects. According to (Hattingh and Viljoen, 2001), probiotics are living bacteria either in a singular or mixed form added to food to benefit the digestive system's health.

The red color of the rosella calyx (Hibiscus sabdariffa Linn) is caused by anthocyanin content. The red color found in rosella tends to be unstable, easily damaged due to environmental influences (Lee and Gould, 2002). One effort to maximize rosella's potential as an antioxidant agent is by modifying it into yogurt preparations. Anthocyanin is generally stable at $\mathrm{pH} 2-5$, so that the application of anthocyanin as a dye can be used in drinks with a low $\mathrm{pH}$. Yogurt usually has a $\mathrm{pH}$ of 44.5 , so that the application of anthocyanin extract can be made on yogurt.

Analysis of anthocyanin content was carried out by the $\mathrm{pH}$ Differential Method (Giusti and Wrolstad, 2005). DPPH is an unstable free radical, so an antioxidant that can stop the oxidation process is anthocyanin. Based on the facts mentioned above, the research aims to get the right formula to make yogurt that is fortified with rosella flowers to have better active substance stability and antioxidant activity.

\section{MATERIALS AND METHOD \\ Materials}

The roselle calyx used in this study were obtained from the Bringharjo market Yogyakarta and were authenticated at Laboratorium Biologi Fakultas MIPA Universitas Ahmad Dahlan. Meanwhile, cream milk (Dancow $\left.{ }^{\circledR}\right)$, Streptococcus thermophilus, and Lactobacillus bulgaricus were obtained from LPT microbiology UGM.

\section{Methods}

This study was conducted with 4 levels of rosella calyx extract $(0 \%, 2 \%, 4 \%$, and $8 \%)$ with honey $8 \%(100 \mathrm{~mL})$ full cream liquid milk, and 5\% bacterial starter combination concentration. (1: 1 $\mathrm{w} / \mathrm{v})$. The quality test of yogurt products was done by testing yogurt's stability with storage at $4{ }^{\circ} \mathrm{C}$ then testing the total anthocyanin and antioxidant activity on days $0,7,14$, and 21 .

The stages of making yogurt include mixing the starter bacteria Lactobacilus bularicus and Streptococcus thermophilus (1:1) each as much as $2.5 \mathrm{~mL}$ and stirring them slowly. $100 \mathrm{ml}$ of Dancow cream milk was pasteurized at $85^{\circ} \mathrm{C}$ for 15 minutes, cooled to $40^{\circ} \mathrm{C}$, then $5 \mathrm{ml}$ of bacterial culture mixture was added, followed by fermentation in an incubator (temperature $35^{\circ} \mathrm{C}$ ) for 16 hours. Then, rosella calyx extract (Hibiscus sabdariffa Linn) and honey were added. Then, the quality of the yogurt was analyzed (Kartikasari and Nisa, 2014). The formula for yogurt preparation can be seen in Table 1 .

Table 1. The formula of yogurt fortified with rosella calyx extract

\begin{tabular}{lcccc}
\hline \multirow{2}{*}{\multicolumn{1}{c}{ Material }} & \multicolumn{4}{c}{ Composition } \\
\cline { 2 - 5 } & FI & FII & FIII & FIV \\
\hline 13\% full cream milk & $100 \mathrm{~mL}$ & $100 \mathrm{~mL}$ & $100 \mathrm{~mL}$ & $100 \mathrm{~mL}$ \\
Starter culture $(\%$ w/v) & 5 & 5 & 5 & 5 \\
Rosella calyx flower extract $(\%$ w/v) & 0 & 2 & 4 & 8 \\
Honey $(\%$ b/v) & 8 & 8 & 8 & 8 \\
\hline
\end{tabular}

* Starter culture used combination of Lactobacillus bularicus and Streptococcus thermophillus (1: 1) $\mathrm{w} / \mathrm{v})$ 


\section{Anthocyanin analysis}

The anthocyanin level test was carried out using UV-Vis spectrophotometry with an analysis of the monomeric anthocyanin method. Yogurt was centrifuged for 45 minutes as much as $20.0 \mathrm{~g}$, taken the supernatant. As much as $25.0 \mathrm{mg}$ of supernatant was into a $25 \mathrm{ml}$ volumetric, then a potassium chloride buffer solution $(0.025 \mathrm{M}) \mathrm{pH} 1$ to a volume of $25 \mathrm{ml}$ was added. $25.0 \mathrm{mg}$ of the supernatant was put into another $25 \mathrm{ml}$ volumetric flask. Then, a sodium acetate (Sigma Aldrich) buffer solution $(0.4 \mathrm{M}) \mathrm{pH} 4.5$ to a volume of $25 \mathrm{ml}$ was added, then placed in a dark place for 60 minutes. UV-Vis spectrophotometer measures the absorption of light from each solution after reaching equilibrium at a wavelength of 457-560 nm with a buffer of $\mathrm{pH} 1$ and a buffer of $\mathrm{pH} 4.5$. Anthocyanins were calculated using equations (1) and (2) (Li et al., 2013).

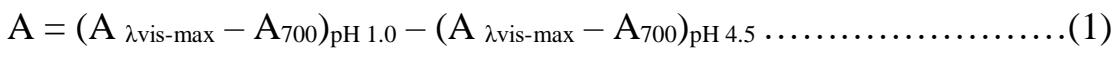

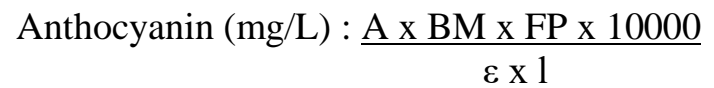

$$
\begin{aligned}
& \mathrm{A}_{\lambda v i s-m a x}: \text { the absorbance at the maximum wavelength } \\
& \mathrm{A}_{700} \quad \text { : the absorbance at } 700 \mathrm{~nm} \\
& \text { A : absorbance } \\
& \text { BM : the molecular weight of cyaniding-3-glycoside }(449,2 \mathrm{~g} / \mathrm{mol}) \\
& \text { FP : dilution factor } \\
& \varepsilon \quad \text { : molar absorptivity of cyanidin-3-glycoside }(26900 \mathrm{~L} / \mathrm{cm} / \mathrm{mol})
\end{aligned}
$$

\section{Antioxidant activity with DPPH method}

A total of $1 \mathrm{~mL}$ of rosella calyx extract with concentrations of $10 \mu \mathrm{g} / \mathrm{mL}, 30 \mu \mathrm{g} / \mathrm{mL}, 50 \mu \mathrm{g} / \mathrm{mL}$, $70 \mu \mathrm{g} / \mathrm{mL}$ and $90 \mu \mathrm{g} / \mathrm{mL}$ was added to $2 \mathrm{~mL}$ DPPH $0.1 \mathrm{mM}$. The mixture was then shaken and incubated at room temperature for 30 minutes in a dark place. This solution was then measured for absorbance of DPPH at $\lambda \max 516 \mathrm{~nm}$. The same treatment was also carried out for blank solutions (DPPH solutions that did not contain test material) and positive control of vitamin $\mathrm{C}$ with concentrations of $2 \mu \mathrm{g} / \mathrm{mL}, 4 \mu \mathrm{g} / \mathrm{mL}, 6 \mu \mathrm{g} / \mathrm{mL}, 8 \mu \mathrm{g} / \mathrm{mL}$, and $10 \mu \mathrm{g} / \mathrm{mL}$. The maxima used for vitamin $\mathrm{C}$ was $515 \mathrm{~nm}$. The blank solution consists of $2 \mathrm{~mL}$ DPPH $0.1 \mathrm{mM}$ and $1 \mathrm{~mL}$ methanol p.a. The absorbance measurement data were analyzed by the percentage of antioxidant activity using the following equation: (Sulandi, 2013).

$$
\% \text { Inhibition }=\underline{(\text { Absorbance blank- Absorbance sample })} \times 100 \%
$$

(Absorbance blank)

\section{Data Analysis}

The analysis was done statistically using Multivariate Analysis of Variance (MANOVA).

\section{RESULT AND DISCUSSION}

Fortification is the addition of macronutrients to add value to food. In this study, yogurt made with rosella extract was added to provide a refreshing sour taste and give yogurt a natural red color. This reddish color indicates the presence of pigments contained in roselle flowers, one of which is anthocyanin. Based on the results of the analysis that has been done, it is known that the maximum wavelength for rosella flower pigment extract is $531 \mathrm{~nm}$. Fortification of rosella calyx extract was carried out in yogurt to maintain the stability of rosella so that the content of anthocyanin compounds and other compounds are not easily damaged. Therefore, in this study, modification of yogurt was done to increase its antioxidant effect. Rosella calyx extract concentrations added in this study were $2 \%, 4 \%$ and $8 \%(\mathrm{v} / \mathrm{v})$. 
In this research, yogurt was made using Streptococcus thermophillus, and Lactobacillus bulgaricus; these bacteria will utilize sugar sources, namely milk and honey, added as energy sources. Lactobacillus bularicus plays a role in the formation of the aroma of yogurt while Streptococcus thermophillus plays a role in the formation of sour, so that the formation of an acidic atmosphere in yogurt can increase the anthocyanin stability of the rosella calyx extract (Mulyani, 2016). Stability of anthocyanin levels of rosella flower extract and rosella calyx extract fortified yogurt is shown in Table 2 .

Table 2. Stability of anthocyanin levels of rosella calyx flower extract and fortified yogurt rosella calyx extract

\begin{tabular}{lccccc}
\hline \multicolumn{5}{c}{ Anthocyanin levels (mg/L) } \\
\hline Sample & Day_0 & Day_7 & Day_14 & Day_21 & Day_28 \\
\hline Rosella extract 2\% & $59.83 \pm 3.03^{\mathrm{aE}}$ & $56.74 \pm 3.86^{\mathrm{aD}}$ & $51.43 \pm 1.54^{\mathrm{Ac}}$ & $44.94 \pm 2.71^{\mathrm{aB}}$ & $37.76 \pm 2.21^{\mathrm{aA}}$ \\
Rosella extract 4\% & $63.45 \pm 0.98^{\mathrm{bE}}$ & $60.86 \pm 0.87^{\mathrm{bD}}$ & $58.36 \pm 0.52^{\mathrm{bC}}$ & $54.46 \pm 0.89^{\mathrm{bB}}$ & $47.48 \pm 3.54^{\mathrm{bA}}$ \\
Rosella extract 8\% & $75.11 \pm 1.31^{\mathrm{cE}}$ & $67.65 \pm 4.25^{\mathrm{cD}}$ & $62.00 \pm 1.71^{\mathrm{cC}}$ & $59.38 \pm 4.14^{\mathrm{cB}}$ & $50.23 \pm 1.61^{\mathrm{Ca}}$ \\
$\begin{array}{l}\text { Yoghurt fortified with } \\
\text { rosella 2\% }\end{array}$ & $56.74 \pm 3.86^{\mathrm{aD}}$ & $54.46 \pm 0.89^{\mathrm{aD}}$ & $51.26 \pm 4.18^{\mathrm{aC}}$ & $50.34 \pm 2.47^{\mathrm{aB}}$ & $46.75 \pm 2.22^{\mathrm{Aa}}$ \\
$\begin{array}{l}\text { Yoghurt fortified with } \\
\text { Rosella 4\% }\end{array}$ & $60.86 \pm 0.87^{\mathrm{bD}}$ & $59.83 \pm 3.03^{\mathrm{bD}}$ & $57.27 \pm 0.82^{\mathrm{bC}}$ & $56.74 \pm 3.86^{\mathrm{bB}}$ & $51.26 \pm 4.18^{\mathrm{Ba}}$ \\
Yoghurt fortified with & $67.11 \pm 3.94^{\mathrm{bD}}$ & $65.65 \pm 2.87^{\mathrm{bD}}$ & $62.00 \pm 1.71^{\mathrm{bC}}$ & $59.83 \pm 3.03^{\mathrm{bB}}$ & $56.75 \pm 3.86^{\mathrm{Ba}}$ \\
Rosella 8\% & & & & & \\
\hline
\end{tabular}

* In the same column with different lowercase letters showed a significant difference with the concentration level of rosella flower extract $(p<0.05)$

${ }^{\mathrm{AE}}$ on the same line with different uppercase letters shows a significant difference with storage time $(\mathrm{p}<0.05)$

The results of this study showed that the total average value of anthocyanin found in fortified yogurt rosella calyx extract at day 28 was higher than that of rosella calyx extracts ranging from 46.75 $\pm 2.22 \mathrm{mg} / \mathrm{L}$ to $56.75 \pm 3.86 \mathrm{mg} / \mathrm{L}$. In contrast, the mean anthocyanin levels in rosella calyx extract on the $28^{\text {th }}$ day ranged from $37.76 \pm 2.21 \mathrm{mg} / \mathrm{L}-50.23 \pm 1.61 \mathrm{mg} / \mathrm{L}$. This shows that rosella calyx extract formulated in yogurt preparations that have a low acidity level can increase the anthocyanin content's stability. This is comparable to (Suzery et al., 2010), which states that anthocyanin tends to be less stable and easily degraded, anthocyanin stability is influenced by $\mathrm{pH}$ and temperature. Anthocyanin is more stable in acidic solutions with low $\mathrm{pH}$ values than with high $\mathrm{pH}$ to have reasonably good stability. According to (Widagdha and Nisa, 2015), the addition of grape juice to yogurt can increase antioxidant activity because wine has one of the antioxidant substances: anthocyanin pigment.

According to (Ariviani, 2010) that anthocyanin compounds have the ability and function as antioxidants. However, anthocyanin is unstable or easily damaged during storage so that it will suffer damage or result in anthocyanin level decrease at the time of storage. The quality of food and processed products will change during storage, and at certain times their quality is no longer acceptable. Antioxidant activity of rosella flower extract and fortified yogurt roselle calyx extract in storage is shown in Table 3.

The results showed that the value of antioxidant activity (\% inhibition) of yogurt fortified with rosella calyx extract on day 0 was higher than that of rosella calyx flower extract. Antioxidant activity of yogurt with rosella calyx extract on day 0 was $60.07 \pm 0.56 \%, 74.17 \pm 0.61 \%$, while inhibition percentage of rosella calyx extract on the day 0 was between $50.91 \pm 0.51 \%, 64.63 \pm 0.68 \%$. This may happen due to the plain yogurt preparations which already have antioxidant activity $(45.48 \pm 1.88 \%)$ obtained from components found in yogurt, so the inhibition percentage is higher in the presence of anthocyanin content from rosella extract and components in yogurt. 
Table 3. Antioxidant activity of rosella calyx flower extract and fortified yogurt rosella calyx flower extract in storage

\begin{tabular}{lccccc}
\hline \multicolumn{7}{c}{ \% Inhibition } \\
\hline Sample & Day_0 & Day_7 & Day_14 & Day_21 & Day_28 \\
\hline Rosella extract 2\% & $50.91 \pm 0.51^{\mathrm{aE}}$ & $46.51 \pm 0.69^{\mathrm{aD}}$ & $37.47 \pm 0.37^{\mathrm{aC}}$ & $30.14 \pm 0.07^{\mathrm{aB}}$ & $25.53 \pm 100^{\mathrm{Aa}}$ \\
Rosella extract 4\% & $59.07 \pm 1.19^{\mathrm{bE}}$ & $57.25 \pm 1.00^{\mathrm{bD}}$ & $54.31 \pm 0.70^{\mathrm{bC}}$ & $51.20 \pm 0.63^{\mathrm{bB}}$ & $47.30 \pm 0.47^{\mathrm{bA}}$ \\
$\begin{array}{l}\text { Rosella extract 8\% } \\
\text { Plain yogurt }\end{array}$ & $64.63 \pm 0.68^{\mathrm{cE}}$ & $61.11 \pm 0.47^{\mathrm{cD}}$ & $56.71 \pm 0.44^{\mathrm{cC}}$ & $54.38 \pm 1.34^{\mathrm{cB}}$ & $50.66 \pm 0.56^{\mathrm{cA}}$ \\
$\begin{array}{l}\text { Yoghurt fortified } \\
\text { with rosella 2\% }\end{array}$ & $60.48 \pm 1.88^{\mathrm{aD}}$ & $39.30 \pm 0.62^{\mathrm{aD}}$ & $35.94 \pm 0.69^{\mathrm{aC}}$ & $27.36 \pm 0.89^{\mathrm{aB}}$ & $19.81 \pm 0.79^{\mathrm{aA}}$ \\
$\begin{array}{l}\text { Yoghurt fortified } \\
\text { with Rosella 4\% }\end{array}$ & $71.68 \pm 0.46^{\mathrm{cD}}$ & $69.15 \pm 0.98^{\mathrm{cD}}$ & $68.07 \pm 0.51^{\mathrm{cC}}$ & $66.87 \pm 0.43^{\mathrm{cB}}$ & $61.07 \pm 0.69^{\mathrm{Ca}}$ \\
$\begin{array}{l}\text { Yoghurt fortified } \\
\text { with Rosella 8\% }\end{array}$ & $74.17 \pm 0.61^{\mathrm{cD}}$ & $71.55 \pm 0.51^{\mathrm{cD}}$ & $70.06 \pm 0.50^{\mathrm{cC}}$ & $69.44 \pm 0.50^{\mathrm{cB}}$ & $63.72 \pm 0.38^{\mathrm{Ca}}$ \\
\hline
\end{tabular}

* In the same column with different lowercase letters showed a significant difference with the concentration level of rosella flower extract $(\mathrm{p}<0.05)$

${ }^{\mathrm{AE}}$ on the same line with different letters show significant differences with storage time $(\mathrm{p}<0.05)$

The critical point $p$-value $<0.05$ showed a significant difference in the treatment (the difference in the concentration of rosella calyx extract) with the duration of storage stability. They were further tested by Tukey HSD to see differences between treatment groups. Tukey HSD test results are known to the three samples: rosella calyx extract $2 \%, 4 \%$, and $8 \%$, respectively, were significantly different. On the storage process, day 0 to 28 differ significantly in line with the decreasing \% inhibition of rosella calyx extract. The research data showed that the highest total antioxidant value from measurement on day 0 was obtained from rosella calyx extract for $8 \%$ concentration of rosella calyx extract, which was $64.63 \pm 0.68 \%$ inhibition. The second highest was the measurement for $4 \%$ concentration of rosella calyx extract with $59.07 \pm 1.19 \%$ inhibition. The lowest antioxidant value was obtained from $2 \%$ concentration of rosella calyx extract with $50.91 \pm 0.51 \%$ inhibition.

Meanwhile, the measurement from the storage process on the $28^{\text {th }}$ day resulted in the highest anthocyanin value of rosella calyx extract was obtained from the concentration of rosella calyx extract $8 \%$ as $50.66 \pm 0.56 \%$, then at the concentration of rosella calyx extract $4 \%$ as $47.30 \pm 0.47 \%$. The lowest anthocyanin value obtained at $2 \%$ rosella calyx extract concentration with $25.53 \pm 1.00 \%$ inhibition. The results showed that the higher levels of anthocyanin compounds in an extract, the antioxidant activity would also increase. This is in line with research by (Mohamed, 2014) which states yogurt as a functional food ingredient because it contains several bioactive compounds, including active peptides and amino acids that act as antioxidants.

\section{CONCLUSION}

The stability of anthocyanin levels of rosella calyx extract was higher than rosella calyx extract yogurt during storage. Yogurt rosella 2\%, 4\%, and $8 \%$ were increased in antioxidant activity during storage, and provision of $4 \%$ and $8 \%$ rosella calyx extract yogurt produces the optimal yogurt formula.

\section{ACKNOWLEDGEMENT}

The authors would thank LPPM UAD for funding this research through the Innovative Research scheme (PIPP).

\section{REFERENCES}

Ariviani, S. (2010). Total antosianin ekstrak buah salam dan korelasinya. Agrointek, 4(2), 121-127.

Giusti, M., \& Wrolstad, R. E. (2005). Characterization and measurement of anthocyanins by UVvisible spectroscopy. Handbook of Food Analytical Chemistry, 2-2, 19-31. 
https://doi.org/10.1002/0471709085.ch18

Hattingh, \& Viljoen. (2001). Yogurt as probiotic carrier food. International Dairy Journal, 11(1-2), 1-17. https://doi.org/10.1016/S0958-6946(01)00036-X

Kartikasari, D. I., \& Nisa, F. C. (2014). The influence of soursop juice addition and fermentation period toward physical chemistry properties of yoghurt. Jurnal Pangan Dan Agroindustri, 2(4), 239-248.

Lee, \& Gould. (2002). Anthocyanins in leaves and other vegetative organs: An introduction. Advances in Botanical Research, 37, 1-16. https://doi.org/10.1016/s0065-2296(02)37040-x

Li, J., Li, X. D., Zhang, Y., Zheng, Z. D., Qu, Z. Y., Liu, M., Zhu, S. H., Liu, S., Wang, M., \& Qu, L. (2013). Identification and thermal stability of purple-fleshed sweet potato anthocyanins in aqueous solutions with various $\mathrm{pH}$ values and fruit juices. Food Chemistry, 136(3-4), 14291434. https://doi.org/10.1016/j.foodchem.2012.09.054

Mohamed, Z. and N. (2014). Physiochemical and sensory evaluation of yoghurt fortified with dietary fiber and phenolic compounds. Life Science Journal, 9860(9), 216-226.

Mulyani, and P. (2016). Profiles of protein levels, fat levels, acidity, and organoleptic soyghurt of banana fruit skin (Musa textile) on temperature and fermentation time variations. 1(2), 48-57.

Sulandi, S. (2013). Aktivitas antioksidan ekstrak kloroform buah lakum dengan metode Dpph (2,2Difenil-1-Pikrilhidrazil). 66, 37-39.

Suzery, Lestari, \& Cahyono. (2010). Penentuan total antosianin dari kelopak bunga rosela (Hibiscus Sabdariffa L) dengan metode maserasi dan sokshletasi. Jurnal Sains Dan Matematika, 18(1), 16.

Widagdha, S., \& Nisa, F. C. (2015). Pengaruh penambahan sari anggur (Vitis vinifera L.) dan lama fermentasi terhadap karakteristik fisiko kimia yoghurt. Jurnal Pangan Dan Agroindustri, 3(1), $248-258$. 